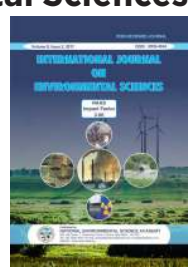

\title{
PRESENT STATUS AND EX-SITU CONSERVATION OF MORINGA CONCANENSIS IN INDIAN DESERT
}

\author{
${ }^{1}$ C.S. Purohit, ${ }^{2 *}$ R. N. Kulloli and ${ }^{3}$ Suresh Kumar \\ ${ }^{1}$ Botanical Survey of India, Andaman \& Nicobar Regional Centre \\ Port Blair-744102, Andaman and Nicobar Island, (India) \\ ${ }^{2}$ Arid Forest Research Institute, Jodhpur, Rajasthan- 34005 (India) \\ ${ }^{3}$ Central Arid Zone Regional Centre, Jodhpur, Rajasthan-342003 (India)
}

\section{Research Article}

Received: 15.08.2020

Revised: 24.08.2020

Accepted: 15.09.2020

\section{ABSTRACT}

Moringa concanensis Nimmo. ex Dalz. \& Gibs. is rare economic important plant distributed in Indian desert. Plant parts are used for different medicinal purposes. Present study was conducted to assess its status in nature as well as different seed germination treatment for its ex-situ conservation. Study revealed that germination was $100 \%$ in coco-peat media while, it was $97.56 \%$ in polythene bags. Seedling mortality was more (39.46\%) in coco-peat media. After transplantation seedlings showed $82 \%$ survival in field.

Keywords: Moringa concanensis, ex-situ conservation, present status, germination, survival.

\section{INTRODUCTION}

Moringaceae, a monogeneric family, having genus Moringa is characterized by a number of species such as Moringa peregrina (M.peregrina), M.oleifera, M.arabica, $M$. stenopetala, $M$. concanensis, $M$. ovalifolia, $M$. hildebrantii, M. arborea, Moringa rivae and Moringa ruspoliana etc. (Tsaknis et al, 1999; Olson, 2003). Almost all Moringa species, native to India are now distributed in many tropical and sub-tropical parts of the world like India, Pakistan, Asia Minor, Africa and Arabia (Mughal et al, 1999). The Moringa plant is an important food of highvalue nutritious properties. Different parts of this plant: root, bark, gum, leaf, fruit (pods), flowers, seed and seed oil have been used for various ailments in the indigenous medicinal practices of south Asia, which included cure for inflammation, cardiovascular, gastrointestinal, hematological and hepatorenal disorders (Morimitsu et al, 2000; Siddhuraju and Becker, 2003). The seeds of the Moringa are considered to exhibit antipyretic and antimicrobial activities, used for water purifying and are also a good source of non-desiccating oil, commercially known as 'Ben oil'.

Though taxonomy and economic value of this plant are intensively studied, information on its regeneration for its ex-situ conservation and its performance in the field is scanty. Hence this study was under taken to answer the issues related to germination and survival as well as its saplings growth to assess its $e x$-situ conservation in garden, arboreta and natural habitats.

\section{TAXONOMY}

Moringa concanensis Nimmo (in Gah. Cat. Bomb. Pl. 43, 1989, nom. nud.) ex Dalz. \& Gibs. Bomb. Fl. 311, 1861; Hook.f. in FBI 2: 45, 1876; BH 26(1): 235, 1918.

Taxonomy Hierarchy (According to India Biodiversity Portal)

Kingdom: Plantae

*Corresponding author: r.kulloli@gmail.com 
Phyllum: Tracheophyta

Class: Magnoliopsida

Subclass: Dilleniidae

Order: Capparales

Family: Moringaceae

Genus: Moringa

S p e cies: $M$.

concanensis

A small tree with thick bark, glabrous. Stem glabrous. Leaves 2-pinnate, rarely 3-pinnate, 30 - 45 cm long, primary and secondary rachises thickened at base, articulated with a single gland at each articulation; leaflets $9-15,1.5-3.4 \times 1.2-2.5 \mathrm{~cm}$, rounded at base, rounded or sometimes retuse at apex, rarely oblique sided, darker above, paler beneath petiolules $2-5 \mathrm{~mm}$ long, jointed near the apex. Inflorescence lax, panicles $40-50 \mathrm{~cm}$ long, tomentose. Flowers small. Pedicels 8 $13 \mathrm{~mm}$ long, deflexed thickened, articulated at the base. bracts $0.5-1 \mathrm{~mm}$ long, caducous. Calyx 5-lobed, lobes oblong, white, reflexed, 8 - $12 \mathrm{~mm}$ long, thinlytomentose. Corolla yellowish-white with reddish near the base, oblong or oblong-spathulate, $1-1.5 \mathrm{~cm}$ long. Stamens 5 with alternating staminodes $4-5$; filaments hairy at base. Pods linear, 30 - $45 \mathrm{~cm}$ long, sharply 3angled, long pointed, valves hard, 10 - 18 seeded. Seeds $1.5-2 \mathrm{~cm}$ long, triangular with a very thin hyaline, wing at each angle, white or pale yellow [Fig. 1].

\section{Local Name: Sarguro}

Fl. \& Fr.: Feb. - May

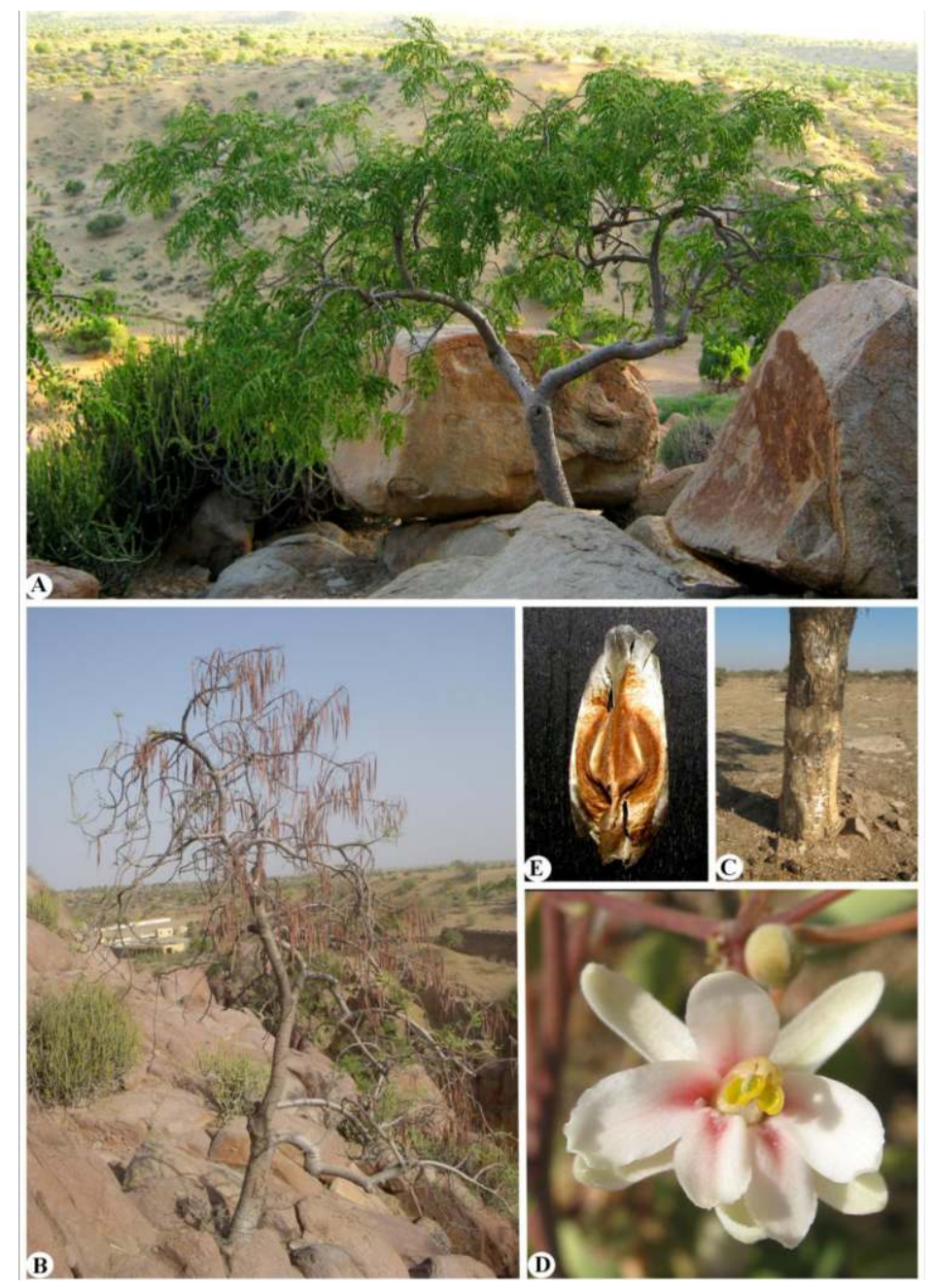

Fig.1. Moringa concanensis A. Habit and Habitat, B. Fruiting, C. Bark removal by local for medicinal purpose, D. Close up of flower and E. Seed 
Distribution: Pakistan, Asia Minor, Africa and Arabia (Mughal et al., 1999).

India:

Hilly region of Eastern Ghats [Pullaiah \& Chennaiah, 1997]; Western Ghats [Prasanna, 2000].

Rajasthan: Jodhpur (Dechu), Barmer (rocky area) [reported by Bhandari, 1990];
Churu (Gopalpura), Jhalawar (Khanpur), Jaisalmer (Near Kuri), Pali (Piproli) and Tonk (Mayola forest) [reported by Shetty \& Singh, 1987];

Barmer, Jodhpur, Jaisalmer, Nagaur, Pali, Bundi, Jhalawar, Jalore [reported by Kumar \& Purohit, 2015] [Fig. 2].

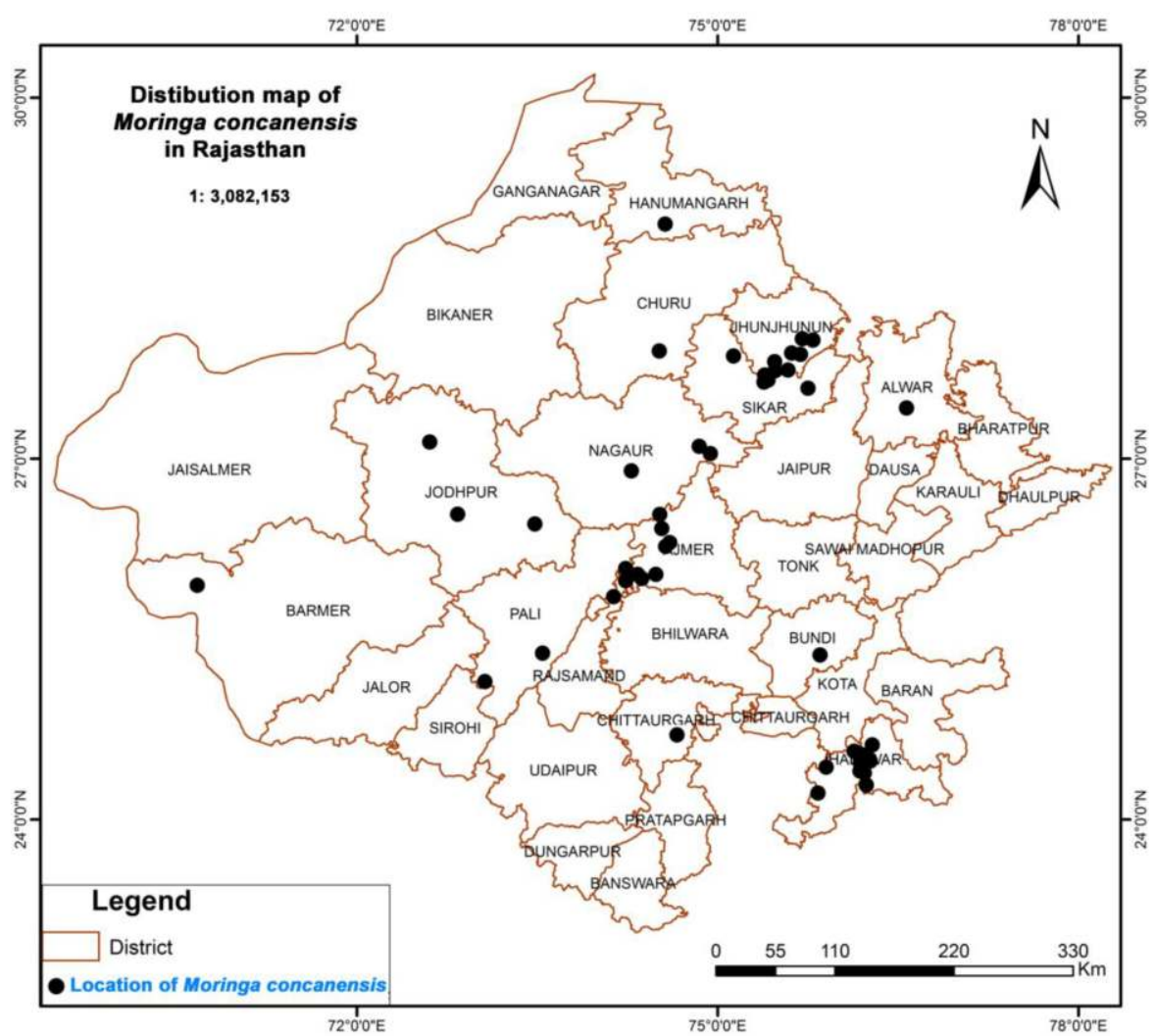

Fig. 2: Distribution map of Moringa concanensis in Rajasthan.

Note: It is a rare plant in Rajasthan. It is a large tree having bipinnate leaves, leaflets $15-30 \mathrm{~mm}$ long and petals with red streaks at base but in M. oleifera is a medium-size tree having tri-pinnate leaves, leaflets 12-18 mm long and petals yellow or white without red streaks. Generic epithet 'Moringa' alludes to the tamil word 'murungai' means drumstick i.e. fruit called drumstick. Specific epither 'concanensis' derived from two word 'concan' means a place Konkan region of Maharashtra and 'sis' means in honour of i.e. the name given on honour of konkan region.
Specific Note: Grahm (1839) in his catalogue states that "A new species discovered by Mr. Nimmo in the South Concan.” But no, description was provided. Later Dalzell \& Gibson (1861) validated the name by providing description. After that Deshpande et al.(2019) has done lectotypification of Moringa concanensis under Art. 9.2 \& 9.11 of the Melbourne Code (McNeill et al., 2012) and image is designated as a lectotype.

Lectotype: INDIA, Maharashtra, Bombay, s.die, N.A. Dalzell s.n. K(K000695641), image! 


\section{EX-SITU CONSERVATION AND PROTOCOL} SUGGESTED

Surveyed on reported localities for mapping and seed collection. Freshly collected seeds were shade dried and soaked in tap water overnight. Seeds kept in a petri-plate in a dark place. Germination was noted daily. On emergence of plumule, seedlings were exposed to sunlight. Although the tree is drought tolerant, its seedlings were watered daily, avoiding water logging. These were then transferred in two sets of polythene bags containing: (1) coconut peat (2) Soil + Farm Yard Manure mixture (Fig 3).

Young seedlings were protected by wire mesh cages for 2-3 months so that they grow better and stronger. Since its roots are very delicate, transplanting in soil requires utmost care. Adequately hardened saplings (4-8 months old) were transplanted at 3m x 3m interval in pits treated with fungicide (Bavistin) and termiticide (Foret). These were regularly irrigated to see its survival and growth (Kumar et al., 2009; Kumar et al., 2010; Purohit et al, 2010a, 2010b; Purohit, 2013).

\section{CONSERVATION TECHNIQUE}

1. Fruit and seed characteristics: Pods collected from Barmer, has average length $29.11 \mathrm{~cm}$ (27-31.5); average pod width $1.73 \mathrm{~cm}$ (1.3-1.9); average seed length $9.76 \mathrm{~mm}$ (6.6-12.1); average seed width 8.28 $\mathrm{mm}$ (7.7-8.6) and average seed weight $0.13 \mathrm{gm}$. Each pod contained 15-20 seeds (Kumar et al., 2010).

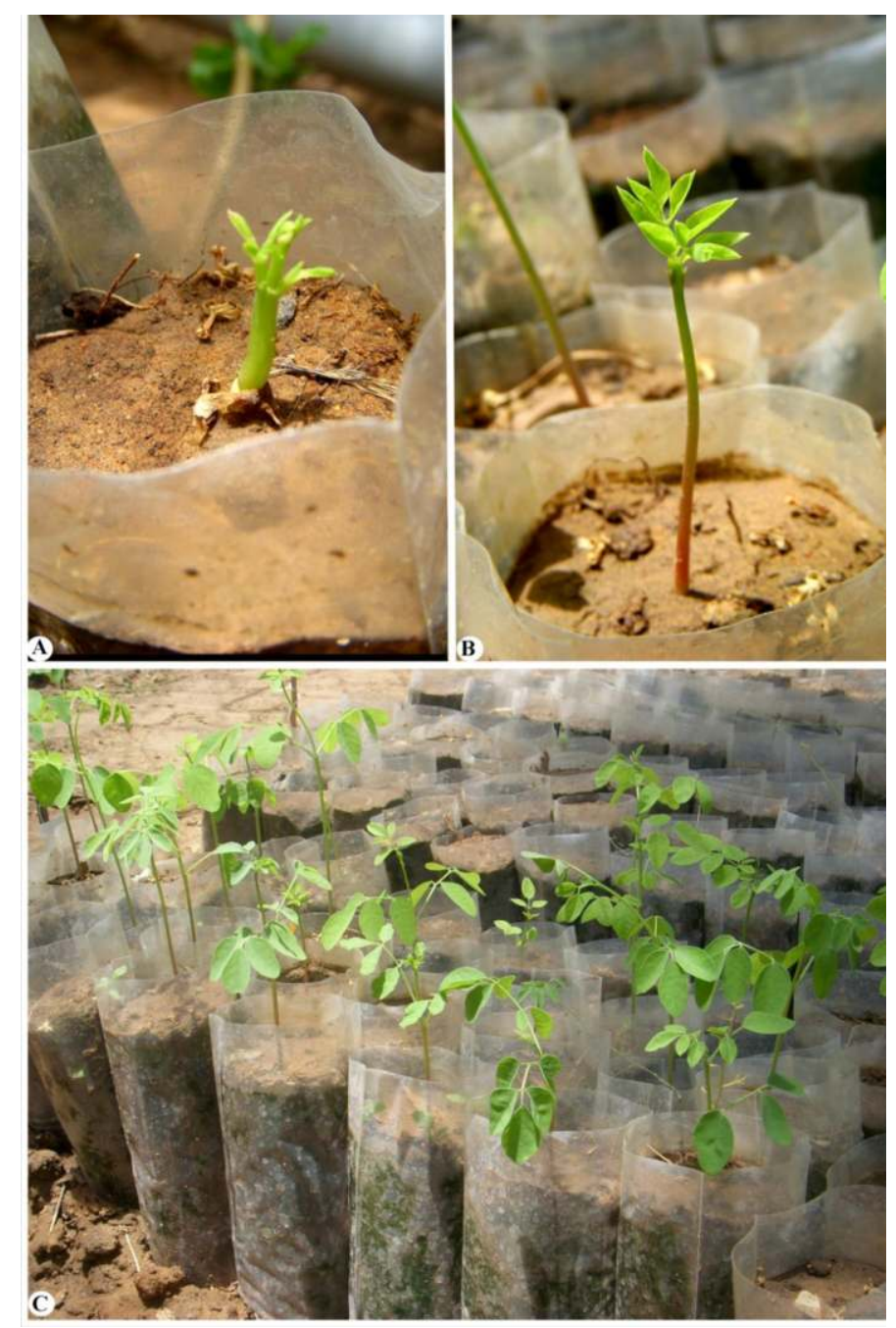

Fig. 3 A to C Different stages of seedling growth in polythene bag. 
Young seedlings were protected by wire mesh cages for 2-3 months so that they grow better and stronger. Since its roots are very delicate, transplanting in soil requires utmost care. Adequately hardened saplings (4-8 months old) were transplanted at 3m x 3m interval in pits treated with fungicide (Bavistin) and termiticide (Foret). These were regularly irrigated to see its survival and growth (Kumar et al., 2009; Kumar et al., 2010; Purohit et al, 2010a, 2010b; Purohit, 2013).

\section{CONSERVATIONTECHNIQUE:}

1. Fruit and seed characteristics: Pods collected from Barmer, has average length $29.11 \mathrm{~cm}$ (27-31.5); average pod width $1.73 \mathrm{~cm}$ (1.3-1.9); average seed length $9.76 \mathrm{~mm}$ (6.6-12.1); average seed width 8.28 $\mathrm{mm}$ (7.7-8.6) and average seed weight 0.13 gm. Each pod contained 15-20 seeds (Kumar et al., 2010).

Table 1 : Comparative analysis between $M$. oleifera and $M$. concanensis.

\begin{tabular}{|l|c|c|}
\hline Characters & M. oleifera & M. concanensis \\
\hline Pod length $(\mathrm{cm})$ & $34.86(29-41.1)$ & $29.11(27-31.5)$ \\
\hline Pod width $(\mathrm{cm})$ & $1.82(1.7-1.9)$ & $1.73(1.3-1.9)$ \\
\hline No. of seeds in a pod & $11-16$ & $15-20$ \\
\hline Seed length $(\mathrm{mm})$ & $11.43(8.7-14.1)$ & $8.76(6.6-12.1)$ \\
\hline Seed width $(\mathrm{mm})$ & $9.26(7.4-10.8)$ & 0.13 \\
\hline Seed weight $(\mathrm{gm})$ & 0.25 & $7.7-8.6)$ \\
\hline
\end{tabular}

2. Germination: All (100\%) seeds germinated within 7-8 days and showed no dormancy. Germination was faster in seeds kept on coconut peat than on garden soil, in polybags. This could be due to more easy availability of moisture in coconut peat than in garden soil (Fig. 4).

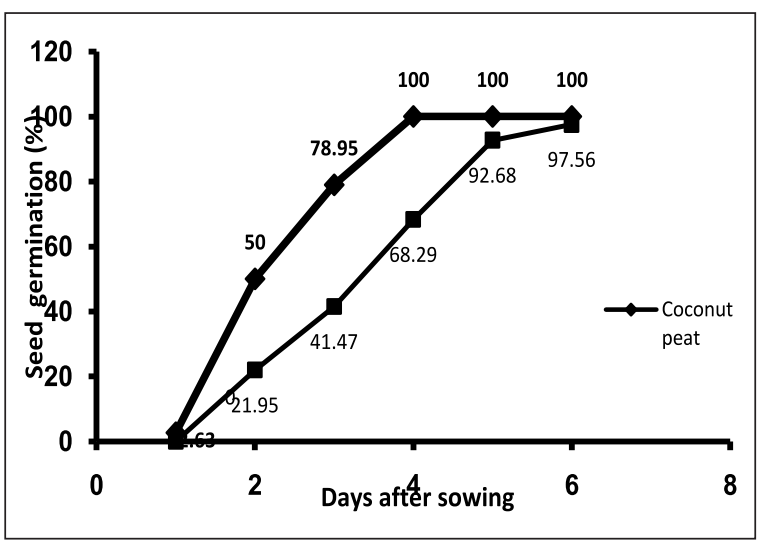

Fig. 4 Seed germination in Coconut peat and FYM + Soil mixture in Polybags (Kumar et al., 2010).

Seedlings in both the media showed similar rate of growth in height (Fig.6) and number of leaves were
3. Seedling Growth: Seedling growth was also rapid in first 3 weeks in coco-peat medium while it took four weeks to attain same height in soil medium. However, seedling mortality was more (39.46) in coco-peat than in soil + FYM (9.76) (Fig. 5).

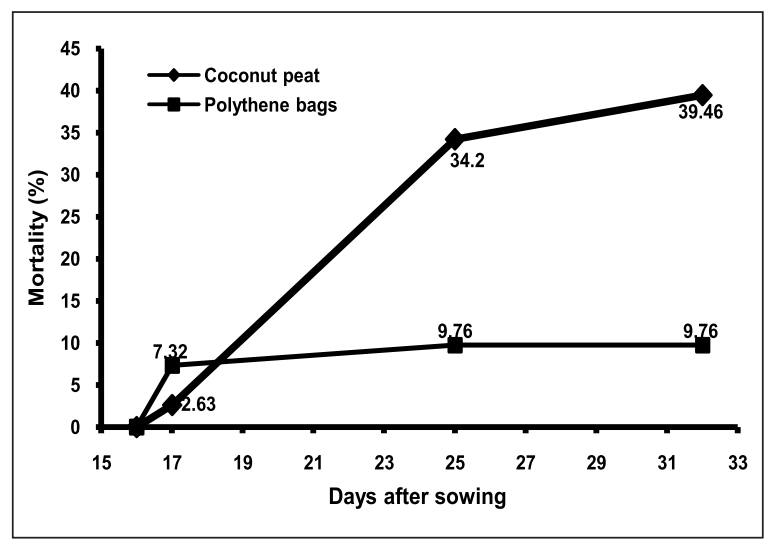

Fig. 5 Mortality in cocopeat peat and polybags (Kumar et al., 2010).

about same (Fig.7) in both medium (coca peat medium and in soil + FYM mixture). 


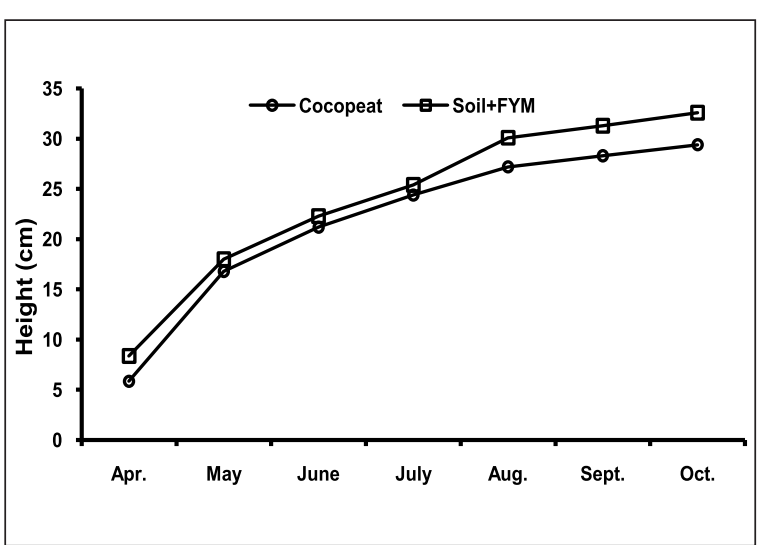

Fig. 6 Plant height in coca peat and soil + FYM mixture (Kumar et al., 2010).

4. Transplantation and survival: When these saplings were $40 \mathrm{~cm}$ tall and eight months old and collar diameter up to $1.6 \mathrm{~cm}$ (Fig. 8) then these were transferred to field. At the time of transfer, care was taken to see that their root system was not disturbed. It was watered daily for 15-20 days and thereafter weekly. Of the 23 saplings transplanted, 19 are surviving showing $82 \%$ survival .

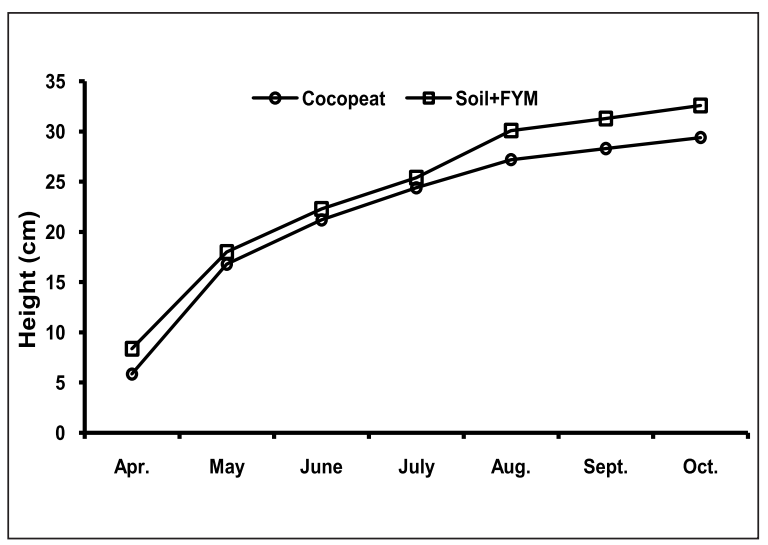

Fig. 8 Collar diameter of $M$. concanensis from first month to 15 months after germination

5. Threats to its Survival: Following threats are observed i.e.

- Most of the seeds are lost along slopes and as such do not reach proper niche for germination and seedling establishment.

- Predation of seeds by goats and sheep is most important threat. Human also eat it.

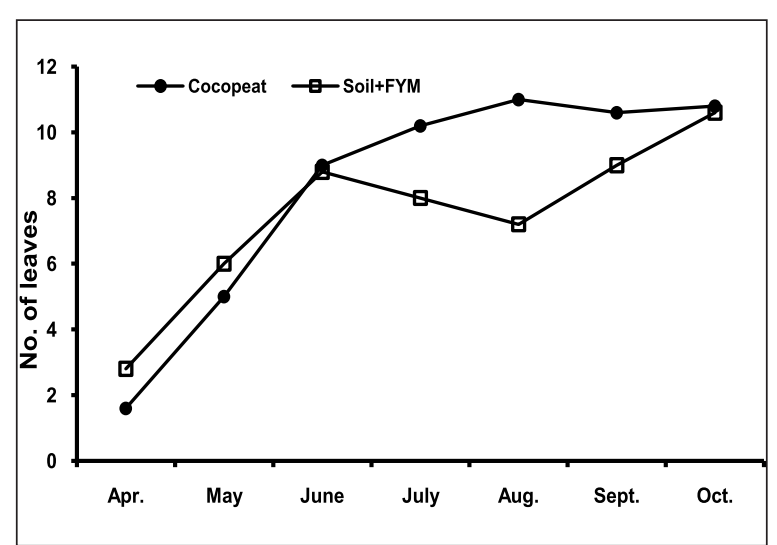

Fig. 7 Number of leaves in coca peat and soil + FYM mixture (Kumar et al., 2010).

- Grazing and browsing of its young saplings by squirrels, birds especially peacocks endangers it most.

- Due to sudden increase in temperature in September and October, it sheds leaves and thereafter its re-growth depends on the availability of water in next rains, which on rocky surfaces may not be available. Thus all young saplings would die in the lack of water.

- Modification and destruction of the habitats through mining has declined its populations.

- The older trees may die due to scrapping of its bark (Fig. 1C). Thus biotic pressure, inhospitable habitat and harsh climatic factors, all potentially limit its spread and result in making it a rarer, endangered species.

\section{PROTOCOL FOR ITS EX-SITU CONSERVATION}

a. Collection of seeds with pods: When the pods split scattering the seeds splash them on surface. These are liked by predator or get physically damaged when fall from such height. So seeds need to be collected as intact pods before split.

b. Shade drying: Seeds are removed from the pod and shade dried. When totally dried seeds may be stored in cotton bags in dry cool places.

c. Shade germination: Seeds are germinated in poly begs with Soil+Cocopeat / Soil+FYM mixture in shade condition. After 5 days seedlings can be partially exposed to sunlight. 
d. Transplantation: When the plant reaches height up to $40 \mathrm{~cm}$ and above saplings can be transferred in the field in pits at $3 \times 3 \mathrm{~m}$ interval. During the plantation, root system should not be disturbed or else plant will die. Termiticide and fungicide are mixed in the soil.

e. Pit specification: Soil should be worked up in $60 \times 60 \times 60 \mathrm{~cm}$ pit. It should be filled with FYM : Pond silt : Local silt in $1: 1: 1$ and treated with termiticide and fungicide.

f. Post plantation care: Young seedlings are eaten by squirrels, birds and peacocks. Hence, it should be protected by wire mesh cages for 2-3 months. In summer, cages should be covered by cloth to protect plants from high temperature and are watered at one day interval.

g. Drying and re-sprout: After three months of transplantation, growth of plant stopped, leaf yellowing started and after one month all leaves fell and whole aerial part became a dry bulb in hibernating condition. During the rainy season, sprouting in the bulb starts re-growth of stem. During this period it should be duly protected.

Thus, above protocol can be followed for ex-situ conservation of Moringa concanensis (Kumar et al., 2010).

\section{ECONOMIC IMPORTANCE}

1. Entire plant parts used to cure inflammation, cardiovascular, gastro-intestinal, hematological disorders.

2. Seed oil has good oxidative stability during frying.

3. The seed oil is high in oleic acid favored for replacing poly-unsaturated vegetable oils.

4. The seed protein can be utilized after value addition, used for water purifying and also a good source of non-desiccating oil, commonly known as Ben Oil.

5. The unripe fruits are eaten by natives.

\section{REFERENCES}

1. Bhandari, M.M. 1990. Flora of the Indian Desert. Scientific Publishers, Jodhpur (Revised Edition).

2. Dalzell, N.A. and Gibson A. (1861). The Bombay Flora: Education Society's Press, Bombay. P. 311.
3. Deshpande, S.M., Gholave, A.R., Kambale, S.S. and Yadav S.R. (2014). Lectotypification of Moringa concanensis (Moringaceae). Rheedea 24(2): 108-109.

4. Grahm, J. (1839). A Catalogue of the plants growing in Bombay and its vicinity. Government Press, Bombay. P. 43.

5. Hooker, J.D. (1879). The Flora of British India, Vol. 2. L. Reeve \& Co., London. Pp.45.

6. Kumar, S. and Purohit, C.S. (2015). Conservation of Threatened desert Plants, page148, Scientific Publishers.

7. Kumar, S., Purohit, C.S. and Kulloli, R.N. (2009). Conservation of rare plant Moringa concanensis Mimmo ex Dalz. \& Gis. In SOUVENIR \& ABSTRACT of XIX Annual Conference of "Indian Association for Angiosperm Taxonomy and International Symposium on Angiosperm Systematics \& Phylogeny; Retrospects \& Prospects” organized by National Botanical Research Institute, Lucknow, 12-14 November, 2009; pp-129.

8. Kumar, S., Purohit, C.S. and Kulloli, R.N. (2010). Ex-situ conservation of rare plant Moringa concanensis Nimmo ex Dalz. \& Gibs. J. Econ. Taxon. Bot. 34(3): 693-698.

9. Latif, Sajid and Anwar Farooq, (2008). Quality assessment of Moringa concanensis seed oil extracted through solvent and aqueous-enzymatic techniques GRASAS Y ACEITES, 59 (1), ENERO-MARZO, 69-75.

10. McNeill, J., Barrie, F.R. Buck, W.R., Demoulin, V., Greuter, W. Hasksworth, D.L., Herendeen, P.S., Knapp, S., Marhold, K., Prado J., Prud'homme van Reine W.F., Smith, G.F., Wiersema, J.H. and Turland, N.J. (2012). International Code of Nomenclature for algae, fungi and plant (Melbourne Code). Regnum Veg. 154. Koeltz Scientific Books, Koenigstein.

11. Morimitsu Y, Hayashi K, Nakagama Y, Horio F, Uchida K, and Osawa T. (2000). Antiplatelet and anticancer isothiocyanates in Japanese horseradish, wasabi. BioFactors 13, 271-276.

12. Mudgal, V., Khanna, K.K. and Hajra, P.K. Flora of Madhya Pradesh Vol. 2. Botanical Survey of India, Kolkata. Pp. 310-311. 
13. Mughal, M.H., Ali G., Srivastava, P.S., Iqbal, M. (1999). Improvement of drumstick (Moringa pterygosperma Gaertn.) - a unique source of food and medicine through tissue culture. Hamdard Med. 42, 37-42.

14. Olson, M.E. (2003). Ontogenetic origins of floral bilateral symmetry in Moringaceae (Brassicales) American Journal of Botany. 90, 49-71.

15. Pullaiah, T. and Chennaiah, E. (1997). Flora of Andhra Pradehs Vol. 1. Scientific Publishers, Jodhpur.

16. Purohit, C.S. 2013. Conservation of Rare plantA case study of Moringa concanensis Nimmo ex Dalz. \& Gibs. in Souvenir \& Abstracts of $23^{\text {rd }}$ Annual Conference of Indian IAAT and National Seminar on 'Recent Advances in Plant taxonomy Research' held at RKM Nagpur University, Nagpur on $27^{\text {th }}$ to $29^{\text {th }}$ Dec. pp 31-32.

16. Purohit, C.S., Kulloli, R.N. and Kumar, S. 2010a. Vilupt Prayah Padap Prajati Sarguda ka Sanrakshan, Maru Krishi Chayanika, CAZRI Publication, 65-67.
17. Purohit, C.S., Kulloli, R.N. and Kumar, S. 2010b Sarguda Padap Prajati Ka Sanrakshan Avum Samvardhan Kheti (Oct) 30-31.

18. Shetty, B.V. and Singh, V. (1988). Flora of India Series 2. Flora of Rajasthan. Botanical Survey of India Vol.1 pp. 196 - 197.

19. Siddhuraju, P, Becker, K. 2003. Antioxidant properties of various solvent extracts of total phenolic constituents from three different agroclimatic origins of drumstick tree Moringa oleifera Lam.). J. Agric. Food Chem. 15, 2144-2155.

20. Singh, N.P. and Karthikeyan, S. (2000). Flora of Maharashtra State, Dicotyledones, Vol.1. Botanical Survey of India.

21. Tsaknis, J., Lalas, S., Gergis, V., Dourtoglou, V. and Spilitois, V. 1999. Characterization of Moringa oleifera variety Mbololo seed oil of Kenya, J. Agric.Food Chem. 47, 4495-4499. 